\title{
Studies on Performance of Self-Grafted Mango Cultivars under Nursery and Field Condition
}

\author{
Harmanbir Singh, Anjil Kumar ${ }^{*}$, Senthil Kumar, Vikas, Rupinder Singh, \\ Sudhir Pratap, Parkash Verma and Ajay Kumar
}

School of Agriculture, Roorkee college of Engineering, Roorkee, 247667, Uttarakhand, India

*Corresponding author

\author{
A B S T R A C T
}

\begin{tabular}{|l|}
\hline Ke y w o r d s \\
Mango, Treatment, \\
$\begin{array}{l}\text { Side veneer } \\
\text { grafting, Rootstock. }\end{array}$ \\
\hline Article Info \\
\hline $\begin{array}{l}\text { Accepted: } \\
\text { 23 September } 2017 \\
\text { Available Online: } \\
\text { 10 October } 2017\end{array}$ \\
\hline \hline
\end{tabular}

The present investigation entitled 'Studies on performance of self-grafted mango cultivars under nursery and field condition in Punjab region' was carried out during 2016 to 2017 in farmers field in village zaffarwal block Dhariwal district Gurdaspur. To assess the performance of self-graft combinations of Dashehari, Langra, Amrappali, Malta, Surkha and Fazli for morphological traits and to evaluate which variety shows higher success in terms of days of sproutning, number of leaves, height and diameter of scion and root stock by using side veneer grafting method done on local root stock. The minimum number of days for sprout (16.10) was found in $\mathrm{T}_{3}$. And the maximum height of Root Stock $(22.23 \mathrm{~cm})$ was reported in the $\mathrm{T}_{5}$ while the maximum diameter of root stock $(9.61 \mathrm{~cm})$ was found in $\mathrm{T}_{4}$. And in case of scion diameter, the maximum diameter of scion $(9.05 \mathrm{~cm})$ found in $T_{1}$ and the maximum number of leaves (6.13) was recorded in $T_{2}$. The research shows that $\mathrm{T}_{3}$ shows higher survival rate of graft and it takes minimum days to develop a new scion then all other varieties and this variety is most compatible to graft in August by using side veneer grafting.

\section{Introduction}

Mango (Magnifera indica) is king of fruits. It has delicious taste and flavour and also has many suitable characters. This crop belongs to Anacardiaceae family. India has $56 \%$ of share in total mango production in the world. In ancient years/times the mango was mainly propagated by stones but now a day different grafting methods are developed and utilized in cultivation of Mangiferaindica. The main advantage of grafting is that it changes the characteristics of plant and makes it superior than its mother plant. Other is that it increases the production by giving fruits in short time as compare to a sexual method of propagation when the plant is raised from seed it gives non-uniform bearing and fruits are inferior. Grafting also play major role in improvement of Inferior varieties. It is common and preferred method of propagation (Bally, 2006).

The main factor in grafting is compatibility. If both root stock and scion are compatible with each other, then growth of new shoot is started. The root stocks are selected on the basis of desirable characters. Seedling with good trait such as rapid growth (in diameter or in height) could reduce the waiting period 
to grafting time. The proper alignments of root stock and scion cambium tissues estimate the graft success (Pina and Errea, 2005).

\section{Materials and Methods}

Field experiment was carried out during the year 2016-17 at farmer's field in village Zaffarwal district Gurdaspur, Punjab to evaluate the performance of different varieties to develop suitable graft combination by evaluating some parameter in nursery and other parameter in field condition.

\section{Experimental details}

The one factor experiment consisting of six treatment combinations was laid out in Randomized Block Design (RBD) with three replications. For each treatment combination grafting operations were performed on five rootstocks.

\section{Observations parameters}

The data on different parameters were recorded at one month interval except the times required for bud sprouting and leaf opening, percentage of graft success and percentage of graft survivability.

Data were recorded daily on bud breaking and leaf opening. The data were collected by taking the following parameters: Number of days for sprout, Height of the grafted plant, Diameter of root stock, Diameter of scion, Number of leaves/plant.

\section{Statistical analysis}

Data were analyzed statistically adopting the technique of analysis of variance (ANOVA).The various comparisons were made after working out the standard errors and critical difference at 5 per cent level of significance.

\section{Results and Discussion}

The minimum number of days for sprout (16.10) was found in $T_{3}$ followed by $T_{5}$ (17.16) while the maximum number of days for sprout (22.60) was taken in $\mathrm{T}_{4}$ (Table 1). The perusal of data revealed that all these early sprouting showed moderate to high yielding potential. Variability in days of sprouting has also been reported by Verma et al., (2012) carried Pusa Navrang as rootstock was proven the most compatible with Pusa Urvashi as scion partner for growth parameters. At 30 days the maximum plant height of grafted plant $(19.26 \mathrm{~cm})$ was observed in $\mathrm{T}_{5}$ which was followed by $\mathrm{T}_{4}$ $(18.40 \mathrm{~cm})$ with at par value. The lowest value of plant height $(15.80 \mathrm{~cm})$ was found in $T_{3}$. These results are also correlated with Chandan et al., (2006) (Table 2). And at 60 days the maximum height of plant $(20.80 \mathrm{~cm})$ was reported in the $T_{5}$. The lowest value in height $(17.33 \mathrm{~cm})$ was found in $T_{3} . A$ significant varietal differences were also observed Sivudu et al., (2014) stated that Banganapalli grafted on Bangalora rootstock recorded the maximum graft height under Anantharajupet conditions. And these results also correlated with Kumar et al., (2012). At 90 Days the maximum height of plant $(22.23 \mathrm{~cm})$ was reported in the $\mathrm{T}_{5}$ and the lowest value of plant height $(18.96 \mathrm{~cm})$ was found in $\mathrm{T}_{3}$. And at 120 days the maximum height of plant $(23.76 \mathrm{~cm})$ was reported in the $\mathrm{T}_{5}$ which was followed by $\mathrm{T}_{4}(23.13 \mathrm{~cm})$. The lowest value of plant height $(20.50 \mathrm{~cm})$ was found in $\mathrm{T}_{3}$. Geetha et al., (1997) observed that grafting success is dependent on the speed of graft union formation. The maximum diameter of root stock $(8.12 \mathrm{~cm})$ was found in $\mathrm{T}_{4}$ and minimum diameter $(6.40 \mathrm{~cm})$ recorded in $\mathrm{T}_{5}$ at 30 days. Bhuiyan et al., (2010) stated that girth was highly influenced by the different combinations of rootstock and scion. At 60 days the maximum diameter of root stock $(8.67 \mathrm{~cm})$ was found in $\mathrm{T}_{4}$ and lowest $(6.95 \mathrm{~cm})$ was found in $\mathrm{T}_{5}$ (Table 3 ). 
Table.1 Number of days for sprout in different varieties of mango

\begin{tabular}{|c|c|}
\hline Treatment & No. of days for sprout \\
\hline $\mathrm{T}_{1}$ & 21.40 \\
\hline $\mathrm{T}_{2}$ & 18.46 \\
\hline $\mathrm{T}_{3}$ & 16.10 \\
\hline $\mathrm{T}_{4}$ & 22.60 \\
\hline $\mathrm{T}_{5}$ & 17.16 \\
\hline $\mathrm{T}_{6}$ & 20.66 \\
\hline C.D. & 1.73 \\
\hline $\mathrm{SE}(\mathrm{m})$ & 0.54 \\
\hline $\mathrm{SE}(\mathrm{d})$ & 0.76 \\
\hline $\mathrm{C} . \mathrm{V}$. & 4.84 \\
\hline
\end{tabular}

Table.2 Height of root stock at different time in different varieties of mango

\begin{tabular}{|c|c|c|c|c|}
\hline Treatments & $\begin{array}{c}\text { Height of root } \\
\text { stock 30 days }\end{array}$ & $\begin{array}{c}\text { Height of root } \\
\text { stock 60 days }\end{array}$ & $\begin{array}{c}\text { Height of root } \\
\text { stock 90 days }\end{array}$ & $\begin{array}{c}\text { Height of root } \\
\text { stock 120 days }\end{array}$ \\
\hline $\mathrm{T}_{1}$ & 16.46 & 18.00 & 19.63 & 21.16 \\
\hline $\mathrm{T}_{2}$ & 18.26 & 19.80 & 21.50 & 23.00 \\
\hline $\mathrm{T}_{3}$ & 15.80 & 17.33 & 18.96 & 20.50 \\
\hline $\mathrm{T}_{4}$ & 18.40 & 19.93 & 21.60 & 23.13 \\
\hline $\mathrm{T}_{5}$ & 19.26 & 20.80 & 22.23 & 23.76 \\
\hline $\mathrm{T}_{6}$ & 18.13 & 19.66 & 21.30 & 22.70 \\
\hline $\mathrm{C} . \mathrm{D}$. & 1.50 & 1.58 & 1.60 & 1.72 \\
\hline $\mathrm{SE}(\mathrm{m})$ & 0.47 & 0.49 & 0.50 & 0.53 \\
\hline $\mathrm{SE}(\mathrm{d})$ & 0.66 & 0.70 & 0.71 & 0.76 \\
\hline $\mathrm{C} . \mathrm{V}$. & 4.60 & 4.47 & 4.17 & 4.17 \\
\hline
\end{tabular}

Table.3 Diameter of root stock at different time in different varieties of mango

\begin{tabular}{|c|c|c|c|c|}
\hline Treatments & $\begin{array}{l}\text { Diameter of root } \\
\text { stock (30 days) }\end{array}$ & $\begin{array}{l}\text { Diameter of root } \\
\text { stock (60 days) }\end{array}$ & $\begin{array}{c}\text { Diameter of root } \\
\text { stock (90 days) }\end{array}$ & $\begin{array}{l}\text { Diameter of root } \\
\text { stock (120 days) }\end{array}$ \\
\hline $\mathrm{T}_{1}$ & 7.63 & 8.18 & 8.60 & 9.13 \\
\hline $\mathrm{T}_{2}$ & 6.74 & 7.29 & 7.71 & 8.23 \\
\hline $\mathrm{T}_{3}$ & 7.37 & 7.92 & 8.34 & 8.86 \\
\hline $\mathrm{T}_{4}$ & 8.12 & 8.67 & 9.08 & 9.61 \\
\hline $\mathrm{T}_{5}$ & 6.40 & 6.95 & 7.55 & 8.07 \\
\hline $\mathrm{T}_{6}$ & 7.66 & 8.21 & 8.64 & 9.16 \\
\hline $\mathrm{CD}$ & 0.25 & 0.59 & 0.62 & 0.72 \\
\hline $\mathrm{SE}(\mathrm{m})$ & 0.08 & 0.18 & 0.19 & 0.22 \\
\hline $\mathrm{SE}(\mathrm{d})$ & 0.11 & 0.26 & 0.27 & 0.32 \\
\hline $\mathrm{CV}$ & 1.92 & 4.09 & 4.07 & 4.46 \\
\hline
\end{tabular}


Table.4 Diameter of scion at different time in different varieties of mango

\begin{tabular}{|c|c|c|c|c|}
\hline Treatments & $\begin{array}{c}\text { Diameter of } \\
\text { scion (30 days) }\end{array}$ & $\begin{array}{c}\text { Diameter of } \\
\text { scion (60 days) }\end{array}$ & $\begin{array}{c}\text { Diameter of } \\
\text { scion (90 days) }\end{array}$ & $\begin{array}{c}\text { Diameter of } \\
\text { scion (120 days) }\end{array}$ \\
\hline $\mathrm{T}_{1}$ & 7.68 & 8.05 & 8.53 & 9.05 \\
\hline $\mathrm{T}_{2}$ & 6.62 & 6.98 & 7.46 & 8.08 \\
\hline $\mathrm{T}_{3}$ & 6.16 & 6.53 & 7.01 & 7.53 \\
\hline $\mathrm{T}_{4}$ & 6.62 & 6.99 & 7.46 & 7.99 \\
\hline $\mathrm{T}_{5}$ & 7.10 & 7.47 & 7.95 & 8.47 \\
\hline $\mathrm{T}_{6}$ & 6.76 & 7.13 & 7.61 & 8.13 \\
\hline $\mathrm{CD}$ & 0.42 & 0.51 & 0.83 & $\mathrm{NS}$ \\
\hline $\mathrm{SE}(\mathrm{m})$ & 0.13 & 0.16 & 0.26 & 0.28 \\
\hline $\mathrm{SE}(\mathrm{d})$ & 0.18 & 0.22 & 0.36 & 0.40 \\
\hline $\mathrm{CV}$ & 3.38 & 3.89 & 5.87 & 6.09 \\
\hline
\end{tabular}

Table.5 Number of leaves at different time in different varieties of mango

\begin{tabular}{|c|c|c|c|c|}
\hline Treatments & $\begin{array}{c}\text { No. of leaves } \\
\text { after 30 days }\end{array}$ & $\begin{array}{c}\text { No. of leaves } \\
\text { after 60 days }\end{array}$ & $\begin{array}{c}\text { No. of leaves } \\
\text { after 90 days }\end{array}$ & $\begin{array}{c}\text { No. of leaves } \\
\text { after 120 days }\end{array}$ \\
\hline $\mathrm{T}_{1}$ & 5.20 & 7.02 & 8.68 & 10.87 \\
\hline $\mathrm{T}_{2}$ & 6.13 & 7.95 & 9.62 & 11.80 \\
\hline $\mathrm{T}_{3}$ & 5.40 & 7.22 & 8.88 & 11.07 \\
\hline $\mathrm{T}_{4}$ & 2.96 & 4.78 & 6.45 & 8.64 \\
\hline $\mathrm{T}_{5}$ & 3.63 & 5.62 & 7.29 & 9.47 \\
\hline $\mathrm{T}_{6}$ & 5.73 & 7.52 & 9.19 & 11.37 \\
\hline $\mathrm{CD}$ & 1.28 & 1.41 & 1.42 & 1.38 \\
\hline $\mathrm{SE}(\mathrm{m})$ & 0.40 & 0.44 & 0.44 & 0.43 \\
\hline $\mathrm{SE}(\mathrm{d})$ & 0.56 & 0.62 & 0.63 & 0.61 \\
\hline $\mathrm{CV}$ & 14.34 & 11.44 & 9.23 & 7.11 \\
\hline
\end{tabular}

Experimental Details

\begin{tabular}{|ll|}
\hline Name of crop & : Mango (Mangiferaindia L.) \\
\hline Scion & : Langra, Daseheri, Surkha,Malta,Fazli,Amrapali \\
\hline Experimental design & $:$ Randomized Block Design \\
\hline (a) Grafting time & $:$ August 2016 \\
\hline (b) Grafting methods & $:$ Side veneer grafting \\
\hline Number of replication & $: 3$ \\
\hline Treatment combination & $: 6$ \\
\hline Treatment unit (tree/treatment $: 5$ \\
\hline Total number of plants & $: 90$ \\
\hline Rootstock used for grafting & $:$ local variety \\
\hline
\end{tabular}




\section{Details of Treatments}

\begin{tabular}{|l|l|}
\hline $\begin{array}{l}\text { Treatments } \\
\text { Variety }\end{array}$ & \\
\hline $\mathrm{T}_{1}$ Daseheri & \\
\hline $\mathrm{T}_{2}$ Amrapali & \\
\hline $\mathrm{T}_{3}$ Surkha & \\
\hline $\mathrm{T}_{4}$ Langra & \\
\hline $\mathrm{T}_{5}$ \\
Malta & \\
\hline $\mathrm{T}_{6}$ Fazli & \\
\hline
\end{tabular}

Temperature, humidity \& rainfall condition at different time

\begin{tabular}{|c|c|c|c|c|c|}
\hline \multirow{2}{*}{ Month } & \multicolumn{2}{|c|}{ Temperature } & \multicolumn{2}{c|}{ Humidity } & \multirow{2}{*}{ RF mm } \\
\cline { 2 - 5 } & $\mathrm{MAX}\left({ }^{\circ} \mathrm{C}\right)$ & $\mathrm{MIN}\left({ }^{\circ} \mathrm{C}\right)$ & $\mathrm{RH} .(\mathrm{M} \%)$ & $\mathrm{RH} .(\mathrm{E} \%)$ & \\
\hline June-2016 & 37.6 & 25.6 & 69.92 & 51.86 & 253.2 \\
\hline July-16 & 33.5 & 25.9 & 86.92 & 75.09 & 234.2 \\
\hline August-16 & 32.8 & 24.9 & 86.24 & 70.69 & 194.5 \\
\hline Sept-16 & 33.1 & 24.2 & 87.45 & 70.47 & 63.3 \\
\hline Oct-16 & 32.1 & 18.3 & 81.34 & 55.22 & 0.1 \\
\hline Nov-16 & 26.4 & 11.6 & 81.03 & 58.74 & 1.0 \\
\hline Dec-16 & 21.8 & 8.5 & 88.93 & 65.83 & 0.0 \\
\hline Jan-2017 & 17.9 & 7.5 & 69 & 69 & 111.4 \\
\hline
\end{tabular}

MAX= Maximum, MIN= Minimum, RH= Relative Humidity, RF= Rainfall, $M=$ Morning, E= Evening

These results also correlated with Singh and Srivastava (1979). The maximum diameter of root stock $(9.08 \mathrm{~cm})$ was found in $\mathrm{T}_{4}$ and lowest $(7.55 \mathrm{~cm})$ was found in $\mathrm{T}_{5}$ at 90 days. The maximum diameter of root stock $(9.61 \mathrm{~cm})$ was found in $\mathrm{T}_{4}$ and lowest $(8.07 \mathrm{~cm})$ was found in $\mathrm{T}_{5}$ at 120 days. Mishra (2012) conducted on experiment to study the effect of scion length, duration of defoliation and poly tube capping on success of wedge grafting in mango cv. Dasehri. At 30 days the maximum diameter of scion $(7.68 \mathrm{~cm})$ found in $\mathrm{T}_{1}$. And the lowest diameter $(6.16 \mathrm{~cm})$ was noted in $T_{3}$. Radhamony et al., (1989) studied the cultivars Priur and Banganapally gave the highest percentage of scion growth. The maximum Diameter of scion $(8.05 \mathrm{~cm})$ was found in $\mathrm{T}_{1}$ and minimum $(6.53 \mathrm{~cm})$ obtained $\mathrm{T}_{3}$ at 60 days. Prasad et al., (1990) studied certain aspects of veneer grafting in mango (Mangifera indica L.) cv. Banganapally in Tirupati. At 90 days the maximum diameter of scion $(8.53 \mathrm{~cm})$ found in $T_{1}$ and the lowest diameter of scion $(7.01 \mathrm{~cm})$ is reported in $\mathrm{T}_{3}$. The maximum Diameter of scion $(9.05 \mathrm{~mm})$ found in $T_{1}$ and minimum $(7.53 \mathrm{~mm})$ noted in $\mathrm{T}_{3}$ at 120 days. Ram and Bist (1982) conducted an experiment to determine the effect of defoliation, diameter of scion and grafting time in mango (Table 4). And at 30 days the maximum number of leaves (6.13) was recorded in $\mathrm{T}_{2}$ and lowest leaves (2.96) were found in $\mathrm{T}_{4}$. Kudmulwar et al., (2008) performed grafting under Parbhani condition using local variety rootstock of custard apple (Annonas quamosa L.) with Balanagar scion and reported the highest number of leaves (21.93) in plants produced after grafting. At 
60 days the highest number of leaves (7.95) was recorded in $\mathrm{T}_{2}$ and lowest leaves (4.78) was found in $\mathrm{T}_{4}$. The research worker has also reported the observation Ram et al., (2012) recorded the maximum number of leaves on Amrapali scion at 30 and 60 days after stone grafting on different cultivars of mango. At 90 days the maximum number of leaves (9.62) was recorded in $\mathrm{T}_{2}$ and lowest leaves (6.45) were found in $\mathrm{T}_{4}$ (Table 5). Gangwar et al., (2003) studied the compatibility behaviour of a plum rootstock with peach scions. They reported that the maximum leaf area was recorded in Flordasum and Kala Amritsari graft combination. At 120 days the maximum number of leaves (11.80) was recorded in $\mathrm{T}_{2}$ and lowest leaves (8.64) were found in $\mathrm{T}_{4}$.

\section{Acknowledgement}

We are extremely grateful to Department of Horticulture for providing all facilities related to our analysis work.

\section{References}

Bally, I. S. E. 2006. Mangifera indica (mango) Anacardiaceae (cashew family). Species Profiles for Pacific Island Agroforestry.

Bhuiyan, M. F. A., Rahim, M. A., and Alam, M. S. 2010. Study on the growth of plants produced by epicotyl (stone) grafting with different rootstock-scion combinations in mango.

Chandan, P. M., Kadam, J. H., and Ambad, S. N. 2006.Effect of different polyembryonic and monoembryonic rootstocks on performance of Dasehrimango. Int. J. Agric. Sci., 2(2): 594-595.

Gangwar, D., Arora, R. L., and Gaur, G. S. 2003.Compatibility Behaviour of Plum Rootstocks with Peach Scions. In VII International Symposium on Temperate
Zone Fruits in the Tropics and Subtropics-Part Two 696 (pp. 177-180).

Geetha, T.K., Valsalakumari, P.K., Geetha, C.K., Rajeevan, P.K. 1997. Influence of polyembryonic rootstocks on the success and survival of soft wood grafts on mango. J. Applied Horti. Nav., 3 (1/2): 85-88

Kudmulwar, R. R., Kulkarni, R. M., Bodamwad, S. G., Katkar, P. B., and Dugmod, S. B. 2008. Standardization of soft wood grafting season on success of custard apple (Annona squamosa L.). Asian J. of Horti, 3(2), 281-282.

Kumar, P. and Thakur, N. 2012.Effect of age of rootstock and different growing media on the success of stone grafting in mango. Int. J. of Farm Sci., 6(1): 255-261.

Mishra, P. 2012. Effect of scion length, duration of defoliation and polytube capping on success of wedge grafting in mango cv. Dasherari. M.Sc. (Ag.) Thesis, IGKV, Raipur.

Pina, A., \& Errea, P. 2005. A review of new advances in mechanism of graft compatibility-incompatibility. Sci. Horti., 106(1): 1-11.

Prasad, P.V., Suryanarayana, V. and Naidu, N. 1990.Studies on certain aspects of veneer grafting in mango (Mangiferaindica L.) cv. Banganapally. SouthInd. Horti, 38(1): 1-7.

Radhamony, P. S., Gopikumar, K. and Valsalakumari, P. K. 1989. Varietal response of scion to stone grafting in mango for commercial propagation. South Ind. Hort., 37 (5): 298-299.

Ram, R.B., Kumar, D., Sonkar, P., Lata, R., and Meena, M. L. 2012.Standardization of stone grafting in some mango cultivars under Lucknow conditions. Hort. Flora. Res. Spec., 1(2): 165-167.

Ram, S., Bist, L.D. 1982. Studies on veneer grafting of mango in Tarai. Punjab Horticultural Journal, 22 (1/2): 64-71. 
Sivudu, B. V., Reddy, M. L. N., Baburatan, P., \& Dorajeerao, A. V. D. 2014. Effect of structural conditions on veneer grafting success and survival of mango grafts (Mangifera indica cv. Banganpalli). Plant Arch, 14: 71-75.

Srivastava, R. P. and Singh, N. P. 1979.A new approach towards double grafting in mango. Current Sci., 49 (17): 678-679.

Verma, S. K., Singh, S. K., Krishna, H., \& Patel, V. B. 2012.Comparative performance of different grafting techniques in grape cv. Pusa Urvashi. Indian J. of Horti, 69(1): 13-19.

\section{How to cite this article:}

Harmanbir Singh, Anjil Kumar, Senthil Kumar, Vikas, Rupinder Singh, Sudhir Pratap, Parkash Verma and Ajay Kumar. 2017. Studies on Performance of Self-Grafted Mango Cultivars under Nursery and Field Condition. Int.J.Curr.Microbiol.App.Sci. 6(10): 2775-2781. doi: https://doi.org/10.20546/ijcmas.2017.610.325 